\title{
Comparative genetic studies of native and introduced Coccinellidae in North America
}

\author{
ELLIOT S. KRAFSUR ${ }^{1}$, JOHN J. OBRYCKI ${ }^{2 *}$ and JAMES D. HARWOOD ${ }^{2}$ \\ ${ }^{1}$ Department of Entomology, Iowa State University, Ames, IA 50011, USA \\ ${ }^{2}$ Department of Entomology, University of Kentucky, S-225 Agricultural Science Center North, Lexington, KY 40546-0091, USA
}

Key words. Coccinellidae, allozyme variation, genetic diversity, colonizing species, biological control

\begin{abstract}
During the past four decades, several species of aphidophagous Coccinellidae became established in North America, including Coccinella septempunctata, Harmonia axyridis, Hippodamia variegata, and Propylea quatuordecimpunctata. After their establishment, unknown circumstances favoured a rapid increase in population densities and distribution of H. axyridis and C. septempunctata at localities hundreds and thousands of kilometers from their release sites. Propylea quatuordecimpunctata and Hippodamia variegata have spread more slowly after becoming established in northeastern North America. Comparative studies based upon allozyme variation in these four introduced species and in six native North American species of ladybird beetles revealed no significant differences in genetic diversities. Genetic variation, assessed by allelic diversity and heterozygosity, was uncorrelated with the establishment and spread of these predatory species in North America. All ladybirds studied show a remarkable degree of dispersion with little detectable population subdivision.
\end{abstract}

\section{INTRODUCTION}

The ecology and genetics of invading organisms have received considerable research attention, yet with notable exceptions (Baker et al., 2003; Hufbauer et al., 2004; Lloyd et al., 2005) little has been accomplished to link improved knowledge of genetics with guidance for the practice of biological control (Roderick, 1992). Questions persist regarding the importance and relationship of genetic variation to the practice of biological control (Unruh \& Messing, 1993; Unruh \& Woolley, 1999; Roderick \& Navajas, 2003).

It is presumed that an important genetic basis for classical biological control is abundant genetic variation in species of natural enemies. Indeed, representative genetic variation has been considered a sine qua non for successful colonization and establishment of natural enemies (Force, 1967; Roush, 1990; Hopper et al., 1993; Baker et al., 2003; Hufbauer et al., 2004; Wajnberg, 2004; Lloyd et al., 2005). Historically, discussions in the literature focused on the merits of collecting natural enemies from marginal vs central populations to maximize variability (Remington, 1968; Myers \& Sabath, 1981). In many projects, the release of well-adapted "biotypes" (= strains, lines, or ecotypes, usage varies among authors) of natural enemies is claimed to have been critical for biological control (Ruberson et al., 1989; Clarke \& Walter, 1995; Unruh \& Woolley, 1999). These geographically separated and typically cryptic populations of parasitic Hymenoptera showed enhanced levels of biological control due to expanded geographic ranges or climatic matching to local conditions. The interpretation of these data from parasitoid studies includes the release of pre-adapted populations and/or post-colonization adaptation and evolution of released populations. However, as discussed by Roderick \& Navajas (2003) evidence for post-colonization adaptation is lacking for predatory species released for biological control. Additionally, for most species of introduced natural enemies, data to support the relationship between genetic variation and levels of biological control is lacking (Unruh \& Woolley, 1999). Recently, however, evidence of mild genetic bottlenecks was documented in populations of the parasitoid wasp Aphidius ervi Haliday (Hymenoptera: Braconidae) and the leafy spurge gall midge Spurgia capitigena (Bremi) (Diptera: Cecidomyiidae), two species that were successfully introduced into North America for biological control (Hufbauer et al., 2004; Lloyd et al., 2005)

A number of releases of exotic ladybird beetle species for biological control have been made in North America, but the results of these efforts have been poor, with an estimated rate of establishment of $\sim 9 \%$ (Gordon, 1985). Do readily observed genetic phenomena underlie this low rate of establishment? Four Palearctic species (Coccinella septempunctata L., Harmonia axyridis (Pallas), Hippodamia variegata (Goeze), and Propylea quatuordecimpunctata L.) that recently have become established in North America may not represent founding of populations introduced for biological control, but rather accidental introductions via transoceanic shipping (reviewed in Obrycki \& Kring, 1998).

We estimated genetic diversities and gene flow in the foregoing Palearctic species (Krafsur \& Obrycki, 1996; Krafsur et al., 1992, 1996a, 1997). In addition, we quantified genetic diversity in the ladybird species, Adalia bipunctata L. and Coleomegilla maculata Degeer (Krafsur et al., 1995, 1996b), and added diversity esti-

\footnotetext{
* Corresponding author; e-mail: John.Obrycki@uky.edu
} 
TABLE 1. Gene diversities in native species of ladybird beetles in North America.

\begin{tabular}{lcccc}
\hline Species $^{1}$ & No. of loci & No. of beetles & Alleles per locus & Heterozygosity \% \\
\hline Coccinella novemnotata & 38 & 38 & 1.71 & $9.6 \pm 2.9$ \\
Coleomegilla maculata & 37 & 56 & 4.00 & $18.3 \pm 3.5$ \\
Cycloneda munda & 40 & 46 & 3.08 & 23.0 \\
Hippodamia convergens & 27 & 44 & 3.03 & $21.3 \pm 4.2$ \\
Hippodamia parenthesis & 34 & 56 & 2.74 & $28.3 \pm 4.5$ \\
Hippodamia tredecimpunctata & 37 & & 1.81 & $7.6 \pm 2.5$ \\
\hline
\end{tabular}

${ }^{1}$ field collected samples only

mates for the Neotropical Eriopis connexa Germar and the Palearctic Scymnus frontalis (F.) coccinellids. To explore whether genetic diversity might influence the ability of ladybirds to establish in North America, we quantified and compared allozyme variation in these introduced and selected indigenous ladybird species. To do so, we present data on the gene diversity of five additional Nearctic species, Coccinella novemnotata Herbst, Cycloneda munda (Say), Hippodamia convergens Guerin, Hippodamia parenthesis (Say), and Hippodamia tredecimpunctata L. and compare diversity among Nearctic and Palearctic Coccinellidae that have recently established in North America.

\section{MATERIAL AND METHODS}

\section{Biological material}

Populations of $C$. novemnotata, $H$. convergens, $H$. parenthesis, H. tredecimpunctata, and C. munda were collected from three locations in North America (Iowa, New York, and Arkansas). Additionally, samples were accepted from available laboratory cultures maintained by the Animal Plant Health Inspection Service, United States Department of Agriculture (APHISUSDA) (Tables 1, 2).

Eriopis connexa and Scymnus frontalis were represented only by specimens taken from USDA-APHIS laboratory cultures. These exotic ladybirds were propagated and released for biological control of the exotic Russian wheat aphid, Diuraphis noxia (Kurdj.) (Hemiptera: Aphididae) but have not become established in North America (Prokrym et al., 1998).

\section{Allozyme variation}

The electrophoretic and staining methods were set forth in our previous studies of ladybirds (e.g. Krafsur et al., 1992, 1996a, b, 1997). A brief overview of methods follows.

\section{Sample preparation, electrophoresis, and staining}

The numbers of each species examined varied from 15 to 88 (Tables 1,2). The entire bodies of adult beetles were homoge- nized individually in $200 \mu 1$ of grinding buffer containing $200 \mathrm{~g}$ sucrose, $50 \mathrm{mg}$ bromophenol blue, $20 \mathrm{mg}$ basic fuchsin (tracking dyes), $770 \mathrm{mg}$ dithiothreotol, and $186 \mathrm{mg}$ ethylenediaminetetracetic acid (EDTA) in $54 \mathrm{mM} \mathrm{pH} 8.9$ Tris-glycine buffer. Two microliters of homogenized sample was applied to each well.

Three buffer systems were used with $6 \%$ polyacrylamide gels: Tris-borate EDTA, pH 9 (TBE), NAM-citrate, 6.5 (Clayton \& Tretiak, 1972), and, for cationic proteins, the Mops system (Thomas \& Hodes, 1981). The TBE electrode and gel buffer consisted of $81 \mathrm{mM}$ Tris, $20 \mathrm{mM}$ borate, and $1.5 \mathrm{mM}$ disodium EDTA. The NAM-citrate gel buffer was $2.7 \mathrm{mM}$ citrate, and the electrode buffer was $5.35 \mathrm{mM}$ citrate, both adjusted to $\mathrm{pH} 6.5$ with N-(3-aminopropyl)-morpholine. The Mops system included 3-(N-morpholino) propanesulfonic acid titrated with $\mathrm{KOH}$ to $\mathrm{pH}$ 6.8. Staining recipes were as prescribed by Murphy et al. (1990), and agar overlays were used for all stains requiring coupling enzymes.

\section{Statistics}

Gene diversity data were analyzed by using BIOSYS-1 (Swofford \& Selander, 1981) and GENES-TATS (Black \& Krafsur, 1985). Genetic diversity at a locus $h_{\mathrm{e}}$, the expected frequency of heterozygotes under Hardy-Weinberg assumptions, was estimated as $h_{\mathrm{e}}=\Sigma p_{i}{ }^{2}$, where $p_{i}$ is the frequency of allele $i$ and the mean over $n$ loci is $H_{\mathrm{E}}=\Sigma h_{\mathrm{e}} / n$ with variance of $\Sigma\left(H_{\mathrm{E}}-\right.$ $\left.h_{\mathrm{e}}\right)^{2} /[n(n-1)](\mathrm{Nei}, 1987) . H_{\mathrm{E}}$ and $h_{\mathrm{e}}$ represent the heterozygosity expected when mating is random and other Hardy-Weinberg assumptions apply. Departures from random mating were estimated in the first instance by the simple statistic, $F=1-h_{0} / h$, where $h_{0}$ is the heterozygosity observed at a locus. $F$ is an inbreeding coefficient and measures reduction in heterozygosity expected on the basis of Hardy-Weinberg criteria. The procedures of Weir \& Cockerham (1984) were used to calculate $F$ statistics. $F_{\mathrm{IS}}$ is the reduction in heterozygosity caused by nonrandom mating within populations and may also be defined as the correlation of uniting gametes in individual beetles within populations. $F_{S T}$ is a measure of nonrandom mating of beetles among populations and is defined as the average correlation of

TABLE 2. Gene diversities in introduced species of ladybird beetles in North America.

\begin{tabular}{lcccc}
\hline Species & No. of loci & No. of beetles & Avg. alleles per locus & Heterozygosity \% \\
\hline Adalia bipunctata $^{1}$ & 39 & 88 & 1.90 & $15.2 \pm 3.3$ \\
Adalia bipunctata $^{3}$ & 30 & 56 & 1.50 & $11.4 \pm 3.7$ \\
Coccinella septempunctata $^{1}$ & 28 & 56 & 2.73 & $18.0 \pm 6.4$ \\
Eriopis connexa $^{3}$ & 21 & 51 & 2.30 & $19.9 \pm 4.4$ \\
Harmonia axyridis $^{1}$ & 51 & 56 & 2.01 & $16.8 \pm 3.0$ \\
Hippodamia variegata $^{2}$ & 28 & 56 & 2.11 & $24.9 \pm 4.9$ \\
Propylea quatuordecimpunctata $^{2}$ & 31 & 56 & 2.29 & $18.3 \pm 2.8$ \\
Scymnus frontalis $^{3}$ & 23 & 15 & 1.57 & $15.3 \pm 5.0$ \\
\hline
\end{tabular}

${ }^{1}$ feral populations only; ${ }^{2}$ averaged over cultured and wild beetles; ${ }^{3}$ laboratory cultures only 
TABLE 3. Gene diversities in North American ladybird beetles.

\begin{tabular}{lccc}
\hline & $\begin{array}{r}\text { No. of } \\
\text { species }\end{array}$ & $\begin{array}{c}\text { Avg. alleles } \\
\text { per locus }\end{array}$ & $\begin{array}{c}\text { Expected } \\
\text { heterozygosity } \%^{2}\end{array}$ \\
\hline Established exotic & 5 & $2.21 \pm 0.33$ & $18.6 \pm 3.7 \%$ \\
Native & 6 & $2.73 \pm 0.86$ & $17.0 \pm 7.9 \%$ \\
\hline
\end{tabular}

${ }^{1} t=1.27, P \sim 0.24 ;{ }^{2} t=-0.41, P \sim 0.69$

gametes in a population relative to the gametes in the entire gene pool. Reproductively isolated populations give a positive $F_{S T}$ because gametes randomly chosen from a population have alleles more often derived from a common ancestor than do gametes from the entire gene pool. Wright (1969) showed that for independently assorting, selectively neutral alleles in island populations at equilibrium, the relationship between $F_{S T}$, local population size $N$, and average rate of immigration $m$ is $F_{S T} \sim(1$ $+4 \mathrm{Nm})^{-1}$. This equation can be solved for $\mathrm{Nm}$, the mean number of reproducing immigrants per population per generation.

\section{RESULTS}

Between 21 and 40 structural gene loci were resolved on gels in six species of native ladybird beetles (Table 1) and seven species of introduced ladybirds (Table 2). The average number of alleles per locus ranged from 1.7 to 4.0 among native species.

Heterozygosity can be interpreted as the probability that two random alleles at an average locus are different. Heterozygosities were least in the endemic $H$. tredecimpunctata $(7.6 \%)$ and in C. novemnotata $(9.6 \%)$. The highest heterozygosities were observed in C. munda $(23 \%)$ and $H$. parenthesis $(28.3 \%)$. Diversities in the introduced ladybirds were comparable. Mean alleles per locus varied from 1.5 in a laboratory culture of $A$. bipunctata to 2.73 in field collected $C$. septempunctata. Heterozygosities varied from 11.4 to $24.9 \%$, thereby indicating no obvious bottlenecks during the laboratory colonization of these taxa. Comparison of diversities between naive and introduced species (excluding the laboratory cultures) showed no significant differences in alleles per locus nor in heterozygosities (Table 3). All the foregoing heterozygosities are greatly underestimated because only $25-30 \%$ of amino acid substitutions in a protein are detectable by one-dimensional electrophoresis (Hartl \& Clark, 1997). Thus, actual allozyme diversities may range from $\sim 30$ to $90 \%$.

Departures from random mating $\left(F_{S T}\right)$ among wild populations varied from 0.01 in C. maculata to 0.06 in $A$. bipunctata (Table 4). The corresponding theoretical mean number of reproducing individuals $\left(N_{e} m\right)$ exchanged among populations varied from 7 to 25 , indicating historically high rates of gene flow.

Departures from random mating among laboratory cultures were much greater than observed in natural populations (Table 4). The reason for the greater $F_{S T}$ estimates is random genetic drift unopposed by gene flow. Note that $N_{e} m$ values are very much less than those recorded for wild beetle populations. $F_{S T}$ among two North American and an Uzbekistan population of $A$. bipunctata was unusually great at 0.43 (Table 4 ), suggesting the possibility that the taxon is a species complex.

\section{DISCUSSION}

Historically, ladybirds were favored for studying the ecological genetics of elytral pattern polymorphisms (Dobzhansky, 1933; Komai, 1956; Sasaji, 1981; Brakefield, 1984; Hodek \& Honěk, 1996). Clines were detected, suggesting the operation of natural selection, however, breeding studies generally showed confounding environmental interactions, multiple alleles, dominance, and for some traits, continuous variation. For example, putative recessive lethals segregating in Adalia bipunctata were suggested to provide a means of ensuring high levels of heterozygosity [see Hodek \& Honěk (1996), for review]. The foregoing properties separately and together greatly confounded the unambiguous examination of gene frequencies in ladybirds and made studies of gene flow impossible until methods became available to estimate and rapidly process selectively neutral, co-dominant, and readily detectable variation.

Possible genetic and ecological factors for the relatively low establishment rate for all introduced natural enemies (34\%) in classical biological control has been discussed widely in the literature (e.g. Hoy, 1985; Waage, 1990). The genetics of a released natural enemy, however, are rarely examined (Hufbauer et al., 2004; Lloyd et al., 2005 ) in relation to the breeding structure of that species that will create an effective population for successful colonization. An understanding of the breeding structure of an introduced natural enemy in their home territories may be a critical component determining the size of releases that are necessary for successful establishment. Without an understanding of the breeding structure of

TABLE 4. Estimates of among-population variance $\left(F_{S T}\right)$ and corresponding estimates of numbers of migrants per generation $\left(N_{e} m\right)$ in some ladybird beetles.

\begin{tabular}{|c|c|c|c|c|c|c|}
\hline & \multicolumn{3}{|c|}{ Field populations } & \multicolumn{3}{|c|}{ Laboratory cultures } \\
\hline & No. populations & $F_{S T}$ & $N_{e} m$ & No. populations & $F_{S T}$ & $N_{e} m$ \\
\hline Adalia bipunctata & 3 & $0.060 \pm 0.01$ & 4 & $2^{\mathrm{a}}$ & $0.428 \pm 0.128$ & 0.3 \\
\hline Coccinella septempunctata & 14 & $0.010 \pm 0.006$ & 25 & 4 & $0.096 \pm 0.025$ & 2 \\
\hline Coleomegilla maculata & 12 & $0.010 \pm 0.004$ & 25 & & & \\
\hline Harmonia axyridis & 8 & $0.025 \pm 0.004$ & 10 & & & \\
\hline Propylea quatuordecimpunctata & 5 & $0.034 \pm 0.021$ & 7 & 5 & $0.331 \pm 0.097$ & 0.5 \\
\hline Hippodamia variegata & $3^{b}$ & $0.107 \pm 0.077$ & 2 & 10 & $0.190 \pm 0.021$ & 1 \\
\hline
\end{tabular}

\footnotetext{
${ }^{a}$ Contrast between North American and $\mathrm{F}_{2}$ Uzbekistan beetles suggests possibility of a species complex; ${ }^{b}$ Two North American and
} one European population 
released natural enemies, development of more effective colonization techniques will be hampered (Hoy, 1985).

During the past 100 years, more than eight aphidophagous coccinellid species became established in North America (Gordon, 1985; Day et al., 1994; Obrycki \& Kring, 1998) e.g., Coccinella undecimpunctata, C. septempunctata, H. axyridis, Harmonia dimidiata (F.) Harmonia quadripunctata, $H$. variegata, and $P$. quatuordecimpunctata. Although propagation and multiple releases of several of these species were made, there remains the likelihood that none became established by deliberate releases of reared stock. Even so, Coccinella septempunctata rapidly expanded its range in the 1970s and 1980s and is now distributed throughout North America (Schaefer et al., 1987; Elliott \& Kieckhefer, 1990a, b; Obrycki et al., 2000; Evans, 2004). In 1988 and 1991, the first detections of $H$. axyridis were made in Louisiana and Georgia, hundreds of kilometers from their release sites (Chapin \& Brou, 1991; Tedders \& Schaefer, 1994). Thereafter, $H$. axyridis rapidly spread in North America and is now found throughout the United States and Canada (Coderre et al., 1995; Dreistadt et al., 1995; LaMana \& Miller, 1996; Nalepa et al., 1996; Krafsur et al., 1997).

Circumstantial evidence suggests that $P$. quatuordecimpunctata was transported to Quebec, Canada, on transoceanic ships using the St. Lawrence Seaway (Day et al., 1994); collections of $P$. quatuordecimpunctata in New York State, however, suggested to Yanega (1996) that a second introduction occurred through the port of New York. It is noteworthy that Old and New World allozyme diversities did not significantly differ. $F_{S T}$ was 0.03 among four feral populations, including New York and one from Western Europe, thereby indicating high rates of gene flow. In contrast, $F_{S T}$ among five geographically diverse laboratory cultures was 0.33 . The data do not support Yanega's (1996) conjecture.

Genetic evidence favors the hypothesis that $H$. variegata, like $P$. quatuordecimpunctata, became established through inadvertent introductions (reviewed in Krafsur et al., 1996a). A number of allozyme alleles in samples from the northeastern USA were unshared with 10 geographically diverse USDA cultures. The USDA cultures were highly differentiated from each other $\left(F_{S T}=0.19\right)$, evidence of strong genetic drift, most of which accumulated in culture. $F_{S T}$ was 0.107 among two North American samples and a field collected sample from Western Europe. But allele frequencies differed significantly among the three populations at only two of nine loci thereby compromising the estimate of differentiation (Krafsur et al., 1996a)

In contrast to the rapid and extensive spread of C. septempunctata and $H$. axyridis, $P$. quatuordecimpunctata and $H$. variegata have spread slowly in northeastern North America (Day et al., 1994; Hoebeke \& Wheeler, 1996; Wheeler \& Stoops, 1996; Yanega, 1996). The remaining introduced species, e.g., C. unidecimpunctata and $H$. quadripunctata, have relatively restricted distributions in North America and have not been well studied.
Due to their restricted distributions and lack of detectable agricultural effects, very little is known about their biology and ecology and their interactions with native species of aphids and ladybird beetles (see Gordon, 1985).

Estimates of genetic variability in a species, while not predictive, are said to be indicative of its evolutionary potential (Reed \& Frankham, 2003). It is often claimed that successful adaptation to the particular habitats where natural enemies are released requires a broad genetic background that includes most, if not all, the genetic variation present in the species gene pool (e.g., Roush, 1990; Hopper et al., 1993). Genetic variation often has strong spatial components. Hopper and Roush's precepts suggest that natural enemy samples for culture and subsequent release should be taken throughout its geographic range and this seems to be the tactic adopted by the USDA. But spatial genetic differentiation is compromised by gene flow and this is as good a reason as any to carry out genetic surveys of candidate natural enemies before attempting to culture them. Our estimates of gene flow, a reciprocal function of $F_{S T}$, indicate that ladybirds disperse widely. Most detectable variation, therefore, exists within populations. Although no estimates of such variation were available to biological control specialists, modern techniques readily allow its estimation (Krafsur et al., 1992, MacDonald \& Loxdale, 2004; Hufbauer, 2004).

For ladybirds, cultures of many tens to hundreds of reproducing beetles will not be subject to rapid loss of diversity of selectively neutral variation by drift. For neutral variation the relationship between diversity $H$ and effective population size $N$ in generation $t$ is, $H_{\mathrm{t}}=H_{0}(1-$ $1 / 2 N)^{\mathrm{t}}$, where $H_{0}$ is heterozygosity in the founding stock (Hartl \& Clark, 1997). Thus, for example, a culture begun with 10 inseminated females $(N=20)$ will lose, by drift, only $2.5 \%$ of its neutral variation in one generation. If breeding population size is maintained at 20 for a further five generations of inbreeding, $12 \%$ will have become lost, and for 10 generations, $22 \%$ will be lost. If $H_{0}$ is only 10 and constrained to that effective size for 10 generations, $40 \%$ of neutral variation will become lost. Thus, loss of genetic variation during a genetic "bottleneck" is the product of effective population size and the number of generations in which population numbers are constricted. Loss of diversity via drift is probably not a serious consideration when breeding up stocks for eventual release because ladybirds are easy to culture and multiple cultures are easily made.

$F_{S T}$ is the among population variance component that measures departures from random mating among populations (Table 4). Among feral populations, estimates of $F_{S T}$ were remarkably small. Small $F_{S T}$ estimates suggest high effective rates of dispersal. Such high dispersal rates argue against strong adaptation to local environments. In contrast, $F_{S T}$ estimates among laboratory cultures were substantial, strong evidence for genetic drift or adaptation to laboratory conditions leading to differentiation of these closed populations while genetic variation remained comparable to wild populations. It is worthy of note, however, 
that allozyme variation is thought to respond to balancing selection, in which heterozygosis per se is at a selective advantage (Kreitman \& Akashi, 1995). A consequence of such balancing selection is to reduce $F_{S T}$ (Schierup et al., 2000). $F_{S T}$ allows estimates of historical effective population size, $\mathrm{Ne}$. According to the island model of population structure, $N_{e} m$ is the hypothetical mean number of reproducing organisms exchanged among subject populations per generation. Some assumptions of the island model include equal exchange among all islands, populations on each island sufficiently large that genetic drift can be ignored, and a negligible mutation rate. Very little genetic exchange among island populations prevents genetic differentiation; only one reproducing organism every generation or two, depending on the population densities. Estimates of $N_{e} m$ among wild beetle populations were very much greater than one.

In summary, genetic studies on ladybirds show: (1) allele diversities and heterozygosities are similar in native and introduced ladybirds and in numerous laboratory cultures. Therefore, there seems to be no obvious relationship between successful colonization of new habitats and genetic diversity, (2) most variation exists within populations and very high rates of gene flow were detected among ladybird populations. This is to be expected in colonizing species whose resources tend to be ephemeral and discontinuously distributed.

At least for aphidophagous ladybirds, questions regarding success or failure of deliberate introductions are unlikely to have easy genetic answers. Clearly, it is worthwhile to examine the breeding structures of candidate biocontrol agents in their home territories, but low indices of genetic differentiation and high genetic diversities are quite unlikely to have any predictive value. In addition, ecological research might best be directed towards (1) varying release numbers, always at moderate densities, in highly replicated trials, (2) examining interactions with prey and native ladybirds at replicate release sites, and (3) checking post release recaptures by using age grading methods to determine if females become gravid and oviposit (Phoofolo et al., 1995).

ACKNOWLEDGEMENTS. Research presented in this paper was partially supported by grants from USDA-APHIS and a grant from the USDA-National Research Initiative. This is publication 05-08-052 of the University of Kentucky Agricultural Experiment Station.

\section{REFERENCES}

BAKer D.A., LoXdale H.D. \& Edwards O.R. 2003: Genetic variation and founder effects of a parasitoid wasp (Diaeretiella rapae): No evidence of host-associated lineages. Mol. Ecol. 12: 3303-3311.

BLACK W.C. IV \& KRAFSUR E.S. 1985: A FORTRAN program for analysis of genotypic frequencies and description of the breeding structure of populations. Theor. Appl. Genet. 70: 484-490.

BRAKEFIELD P.M. 1984: Ecological studies on the polymorphic ladybird Adalia bipunctata in the Netherlands 1. Population biology and geographical variation of melanism. J. Anim. Ecol. 53: 761-774.
ChAPIN J.B. \& Brou V.A. 1991: Harmonia axyridis (Pallas), the third species of the genus to be found in the United States (Coleoptera: Coccinellidae). Proc. Entomol. Soc. Wash. 93: 630-635.

Clarke A.R. \& Walter G.H. 1995: "Strains" and the classical biological control of insect pests. Can. J. Zool. 73: $1777-1790$

Clayton J.W. \& Tretiak D.N. 1972: Amine-citrate buffers for $\mathrm{pH}$ control in starch gel electrophoresis. J. Fish. Res. Board Can. 29: 1169-1172.

Coderre D., Lucas E. \& Gagne I. 1995: The occurrence of Harmonia axyridis (Pallas) (Coleoptera: Coccinellidae) in Canada. Can. Entomol. 127: 609-611.

Day W.H., Prokrym D.R., Ellis D.R. \& Chianese R.J. 1994: The known distribution of the predator Propylea quatuordecimpunctata (Coleoptera: Coccinellidae) in the United States, and thoughts on the origin of this species and five other exotic lady beetles in eastern North America. Entomol. News 105: 244-256.

Dreistadt S.H., Hagen K.S. \& BeZark L.G. 1995: Harmonia axyridis (Pallas) (Coleoptera: Coccinellidae), first western United States record for this Asiatic lady beetle. Pan Pac. Entomol. 71: 135-136.

DoBZHANSKY T. 1933: Geographical variation in lady-beetles. Am. Nat. 67: 97-126.

ElLIOTT N.C. \& KieCKHEFER R.W. 1990a: A thirteen-year survey of the aphidophagous insects of alfalfa. Prairie Nat. 22: $87-96$

Elliott N.C. \& KieckHefer R.W. 1990b: Dynamics of aphidophagous coccinellid assemblages in small grain fields in eastern South Dakota. Environ. Entomol. 19: 1320-1329.

Evans E.W. 2004: Habitat displacement of North American ladybirds by an introduced species. Ecology 85: 637-647.

ForCE D.C. 1967: Genetics in the colonization of natural enemies for biological control. Ann. Entomol. Soc. Am. 60: $722-729$.

Gordon R.D. 1985: The Coccinellidae (Coleoptera) of America north of Mexico. J. N.Y. Entomol. Soc. 93: 1-912.

Hartl D.L. \& Clark A.G. 1997: Principles of Population Genetics. Sinauer Associates, Sunderland, MA, 180 pp.

Hoebere E.R \& Wheeler A.G. 1996: Adventive lady beetles (Coleoptera: Coccinellidae) in the Canadian maritime provinces, with new eastern U.S. records of Harmonia quadripunctata. Entomol. News 107: 281-290.

Hodek I. \& HonĚK A. 1996: Ecology of Coccinellidae. Kluwer Academic Publishers, Dordrecht, 464 pp.

Hopper K.R., Roush R.T \& Powell W. 1993: Management of genetics of biological control introductions. Annu. Rev. Entomol. 38: $27-51$.

Hoy M.A. 1985: Improving establishment of arthropod natural enemies. In Hoy M.A. \& Herzog D.C. (eds): Biological Control in Agricultural IPM Systems. Academic Press, New York, pp. 151-166.

HUFBAUER R.A. 2004: Population genetics of invasions: Can we link neutral markers to management? Weed Tech. 18: $1522-1527$.

Hufbauer R.A., Bogdanowicz S.M. \& Harrison R.G. 2004: The population genetics of a biological control introduction: mitochondrial DNA and microsatellite variation in native and introduced populations of Aphidius ervi, a parasitoid wasp. Mol. Ecol. 13: 337-348.

Komai T. 1956: Genetics of ladybeetles. Adv. Genetics 8: 155-188.

KRAFSUR E.S. \& OBRYCKI J.J. 1996: Gene flow in the exotic 14spotted ladybird beetle, Propylea quatuordecimpunctata. Genome 39: 131-139.

Krafsur E.S., Obrycki J.J. \& Flanders R.V. 1992: Gene flow in populations of the seven-spotted lady beetle, Coccinella septempunctata. J. Heredity 83: 440-444. 
Krafsur E.S., Obrycki J.J. \& Schaefer P.W. 1995: Genetic heterozygosity and gene flow in Coleomegilla maculata DeGeer (Coleoptera: Coccinellidae). Biol. Control 5: 104-111.

Krafsur E.S., Obrycki J.J. \& Nariboli P. 1996a: Gene flow in colonizing Hippodamia variegata ladybird beetle populations. J. Heredity 87: 41-47.

Krafsur E.S., Nariboli P. \& Obrycki J.J. 1996b: Gene flow and diversity at allozyme loci in the two spotted lady beetle (Coleoptera: Coccinellidae). Ann. Entomol. Soc. Am. 89: 410-419.

Krafsur E.S., Kring T.J., Miller J.C., Nariboli P., Obrycki J.J., Ruberson J.R. \& Schaefer P.W. 1997: Gene flow in the exotic colonizing ladybeetle Harmonia axyridis in North America. Biol. Control 8: 207-214

KreitMAn M. \& AKASHI H. 1995: Molecular evidence for natural selection. Annu. Rev. Ecol. Syst. 26: 403-422.

LaMana M.L. \& Miller J.C. 1996: Field observations on Harmonia axyridis Pallas (Coleoptera: Coccinellidae) in Oregon. Biol. Control 6: 232-237.

Lloyd C.J., Hufbauer R.A., Jackson A., Nissen S.J. \& Norton A.P. 2005: Pre- and post-introduction patterns in neutral genetic diversity in the leafy spurge gall midge, Spurgia capitigena (Bremi) (Diptera: Cecidomyiidae). Biol. Control 33: $153-164$.

MacDonald C. \& Loxdale H.D. 2004: Molecular markers to study population structure and dynamics in beneficial insects (predators and parasitoids). Inter. J. Pest Manag. 50: 215-224.

Murphy R.W., Sites J.W., Buth D.G. \& Haufler C.H. 1990: Proteins I: Isozyme electrophoresis. In Hillis D.M. \& Moritz C. (eds): Molecular Systematics. Sinauer Associates, Sunderland, MA, pp. 45-126.

Myers J.H. \& Sabath M.D. 1981: Genetic and phenotypic variability, genetic variance, and the success of establishment of insect introductions for the biological control of weeds. In Proc. 5th Inter. Symposium for the Biological Control of Weeds. Brisbane, Australia, pp. 91-102.

Nalepa C.A., KidD K.A. \& Ahlstrom K.R. 1996: Biology of Harmonia axyridis (Coleoptera: Coccinellidae) in winter aggregations. Ann. Entomol. Soc. Am. 89: 681-685.

NeI M. 1987: Molecular Evolutionary Genetics. Columbia University Press, New York, 512 pp.

OBRYCKI J.J. \& KRING T.J. 1998: Predacious Coccinellidae in biological control. Annu. Rev. Entomol. 43: 295-321.

Obrycki J.J., Elliott N.C. \& Giles K.L. 2000: Coccinellid introductions: potential for and evaluation of non-target effects. In Follett P. \& Duan J. (eds): Nontarget Effects of Biological Control. Kluwer, Dordrecht, pp. 127-145.

Phoofolo M.W., Obrycki J.J. \& Krafsur E.S. 1995 Temperature-dependent ovarian development in Coccinella septempunctata (Coleoptera: Coccinellidae). Ann. Entomol. Soc. Am. 88: 72-79.

Prokrym D.R., Pike K.S. \& Nelson D.J. 1998: Biological control of Diuraphis noxia (Homoptera: Aphididae): Implementation and evaluation of natural enemies. In Quisenberry S.S. \& Peairs F.B. (eds): A Response Model for an Introduced Pest the Russian Wheat Aphid. Thomas Say Publications in Entomology, Entomological Society of America, Lanham, MD, pp. $183-208$.

Reed D.H. \& Frankham R. 2003: Correlation between fitness and genetic diversity. Conserv. Biol. 17: 230-237.

REMINGTON C.L. 1968: The population genetics of insect introductions. Annu. Rev. Entomol. 13: 415-426.

RoDERICK G.K. 1992: Postcolonization evolution of natural enemies. In Kauffman W.C. \& Nechols J.R. (eds): Selection Criteria and Ecological Consequences of Importing Natural
Enemies. Thomas Say Publications in Entomology, Entomological Society of America, Lanham, MD, pp. 71-86.

Roderick G.K. \& Navajas M. 2003: Genes in new environments: Genetics and evolution in biological control. Nature Rev. Gen. 4: 889-899.

Roush R.T. 1990: Genetic variation in natural enemies: critical issues for colonization in biological control. In Mackauer M., Ehler L. \& Roland J. (eds): Critical Issues in Biological Control. Intercept, Andover, Hants., UK, pp. 263-288.

Ruberson J.R., TAuber M.J. \& TAuber C.A. 1989: Intraspecific variability in Hymenopteran parasitoids: Comparative studies of two biotypes of the egg parasitoid Edovum puttleri (Hymenoptera: Eulophidae). J. Kans. Entomol. Soc. 62: 189-202.

SASAJI H. 1981: Biosystematics on Harmonia axyridis-complex (Coleoptera: Coccinellidae). Mem. Fac. Educ. Fukui Univ. Ser II (Nat. Sci.) 30: 59-79.

Schaefer P.W., Dysart R.J. \& Specht H.B. 1987: North American distribution of Coccinella septempunctata (Coleoptera: Coccinellidae) and its mass appearance in coastal Delaware. Environ. Entomol. 16: 368-373.

Schierup M.H., Charlesworth D. \& Vekemans X. 2000: The effect of hitch-hiking on genes linked to a balanced polymorphism in a subdivided population. Genet. Res. 76: 63-73.

SwOFFORD D.L. \& SElANDER R.B. 1981: BIOSYS-1: a FORTRAN program for the comprehensive analysis of electrophoretic data in population genetics and systematics. J. Heredity 72: 281-283.

Tedders W.L. \& Schaefer P.W. 1994: Release and establishment of Harmonia axyridis (Coleoptera: Coccinellidae) in the southeastern United States. Entomol. News 105: 228-243.

THOMAS J.M. \& Hodes M.E. 1981: A new continuous buffer system for the electrophoresis of cationic proteins at nearneutral pH. Anal. Biochem. 118: 194-196.

UnRUh T.R. \& Messing R.H. 1993: Intraspecific biodiversity in Hymenoptera: Implications for conservation and biological control. In LaSalle J. \& Gauld I.D. (eds): Hymenoptera and Biodiversity. CAB International, Wallingford, Oxon, UK, pp. $27-52$.

UnRUh T.R. \& WoOlley J.B. 1999: Molecular methods in classical biological control. In Bellows T.S. \& Fisher T.W. (eds): Handbook of Biological Control. Academic Press, New York, pp. $57-85$.

WAAGE J.K. 1990: Ecological theory and the selection of biological control agents. In Mackauer M., Ehler L.E. \& Roland J. (eds): Critical Issues in Biological Control. Intercept, Andover, UK, pp. 135-157.

WAJNBERG E. 2004: Measuring genetic variation in natural enemies used for biological control: Why and how? In Ehler L.E., Sforza R. \& Mateille T. (eds): Genetics, Evolution and Biological Control. CAB International, Wallingford, Oxon UK, pp. 19-37.

WeIR B.S. \& Cockerham C.C. 1984: Estimating F-statistics for the analysis of population structure. Evolution 38: $1358-1370$

WheELER A.G. \& Stoops C.A. 1996: Status and spread of the Palearctic lady beetles Hippodamia variegata and Propylea quatuordecimpunctata (Coleoptera: Coccinellidae) in Pennsylvania, 1993-1995. Entomol. News 107: 291-298.

Wright S. 1969: Evolution and the Genetics of Populations. Vol. 2. The Theory of Gene Frequencies. University of Chicago Press, Chicago, IL, 511 pp.

YANEGA D. 1996: Records of Propylea quatuordecimpunctata (Coleoptera: Coccinellidae) from Long Island, New York: Evidence for a naturalized population before 1991. Entomol. News 107: 36-38.

Received May 2, 2005; revised and accepted June 3, 2005 